Hal. 323 - 335

\title{
FAKTOR-FAKTOR YANG MEMPENGARUHI KINERJA PEMERINTAH DESA MELALUI PENGELOLAAN KEUANGAN DESA SEBAGAI VARIABEL INTERVENING
}

\author{
Dina Rulyanti \\ Dinas Pendapatan dan Pengelolaan Keuangan Kabupaten Bondowoso \\ dina.rulyanti@yahoo.com \\ Raden Andi Sularso \\ Fakultas Ekonomi dan Bisnis Universitas Jember \\ Manajemen1234@yahoo.com \\ Yosefa Sayekti \\ Fakultas Ekonomi dan Bisnis Universitas Jember \\ yosefa_sayekti@yahoo.com
}

\begin{abstract}
This research aimed to empirically analyze the effects of regulation, organizational commitment, communication, and human resources on the performance of the government of the villages in Bondowoso Regency, East Java Province, mediated by the financial management. The sample was 187 respondents consisted of the heads of the villages, secretaries of the villages, heads of the departments, and treasurers. Data were analyzed using Structural Equation Modeling (SEM). Results show that organizational commitment and human resources have significant and positive effects on the financial management and the performance of the village government. However, regulation and communication have no significant effects on the financial management and the performance of the village government.
\end{abstract}

Keywords: Local Government Performance, Village's Finances, Village's Financial Management.

\begin{abstract}
Abstrak: Penelitian ini bertujuan untuk mencari bukti empirik pengaruh regulasi, komitmen organisasi, komunikasi, dan sumber daya manusia terhadap kinerja Pemerintah Desa di Kabupaten Bondowoso Jawa Timur jika dimediasi oleh pengelolaan keuangan desa. Sampel yang digunakan dalam penelitian ini sebanyak 187 responden, yang terdiri dari kepala desa, sekretaris desa, kepala seksi/kaur, dan bendahara. Data dianalisis menggunakan SEM. Hasil penelitian menunjukkan bahwa komitmen organisasi dan sumber daya manusia berpengaruh positif signifikan terhadap pengelolaan keuangan desa dan kinerja pemerintah desa, sedangkan regulasi dan komunikasi tidak berpengaruh signifikan terhadap pengelolaan keuangan desa dan kinerja pemerintah desa.
\end{abstract}

Kata Kunci: Kinerja Pemerintah Desa, Keuangan Desa, Pengelolaan Keuangan Desa.

\section{Pendahuluan}

Kebijakan otonomi daerah melalui Undang-undang Nomor 32 Tahun 2004 memberikan otonomi yang luas kepada daerah untuk menyelenggarakan pemerintahannya sendiri. Kebijakan otonomi daerah tersebut tentunya juga berimplikasi terhadap sistem 
administrasi pemerintahan desa (Solekhan, 2014: 9). Undang-undang Nomor 6 Tahun 2014 berhasil menggabungkan fungsi self governing community dengan local self government, sehingga desa memenuhi syarat entitas pelaporan, (Hoesada, 2016: 37). Seiring dengan diterbitkannya Undang-undang desa tersebut, maka pemerintah pusat memberikan aliran dana tambahan kepada desa diluar alokasi dana desa yang sudah diterima desa setiap tahunnya, yaitu dana desa. Dana desa merupakan dana yang bersumber dari Anggaran Pendapatan dan Belanja Negara yang diperuntukkan bagi desa yang ditransfer melalui Anggaran Pendapatan dan Belanja Daerah Kabupaten/Kota dan digunakan untuk membiayai penyelenggaraan pemerintahan, pelaksanaan pembangunan, pembinaan kemasyarakatan, dan pemberdayaan masyarakat (Peraturan Pemerintah Nomor 60 Tahun 2014). Dengan adanya dana desa yang diterima desa dari pemerintah pusat mulai tahun 2015, maka penerimaan desa mengalami peningkatan yang cukup besar, sehingga desa dituntut untuk lebih akuntabel dalam mengelola keuangannya.

Teori hierarki norma hukum oleh Hans Kelsen menyebutkan bahwa norma-norma hukum itu berjenjang-jenjang dan berlapis-lapis dalam suatu hierarki, dimana suatu norma yang lebih rendah berlaku, bersumber, dan berdasar pada norma yang lebih tinggi (Soeprapto, 1998: 25). Undang-undang Nomor 12 Tahun 2011 menjelaskan bahwa pengertian peraturan perundang-undangan adalah peraturan tertulis yang memuat norma hukum yang mengikat secara umum dan dibentuk atau ditetapkan oleh lembaga negara atau pejabat yang berwenang melalui prosedur yang ditetapkan dalam peraturan perundang-undangan. Regulasi memegang peranan penting dalam pengelolaan keuangan desa, karena regulasi merupakan dasar dalam pelaksanaan pengelolaan keuangan desa. Pengelolaan keuangan desa diatur oleh sekumpulan regulasi mulai dari yang tertinggi yaitu Undang-undang Nomor 6 Tahun 2014 tentang desa sampai regulasi yang paling bawah yaitu peraturan desa. Dengan adanya sekumpulan peraturan yang terkait dengan desa dan pengelolaan keuangannya, maka diharapkan dapat meningkatkan pembangunan masyarakat desa terutama dalam melaksanakan pengelolaan keuangan desa yang lebih akuntabel dan transparan. Selain itu, dengan adanya pengelolaan keuangan desa yang baik diharapkan dapat mempengaruhi kinerja pemerintah desa, dimana semakin tinggi aturan yang diterapkan oleh perangkat desa maka akan meningkatkan kualitas kinerja perangkat desa.

Lubis (2010: 54) menjelaskan bahwa komitmen organisasi merupakan tingkat sampai sejauh mana seorang karyawan memihak pada suatu organisasi tertentu dan tujuan-tujuannya serta berniat mempertahankan keanggotaannya dalam organisasi tersebut. Komitmen organisasi merupakan salah satu faktor yang berpengaruh terhadap pengelolaan keuangan desa, karena komitmen organisasi berasal dari diri individu masingmasing untuk melakukan tindakan yang dapat memberikan dampak positif bagi organisasi. 
Sehingga diharapkan dengan adanya komitmen yang tinggi dari kepala desa beserta perangkat desa, maka dapat meningkatkan kualitas pengelolaan keuangan desa dan secara tidak langsung juga akan meningkatkan kinerja aparatur desa itu sendiri. Pegawai atau karyawan dengan komitmen yang tinggi diharapkan akan memperlihatkan kinerja yang optimal. Seseorang yang bergabung dalam organisasi pada sebuah perusahaan dituntut adanya komitmen dalam dirinya (Halim, 2012).

Komunikasi organisasi merupakan pengiriman dan penerimaan berbagai pesan di dalam organisasi dan di dalam kelompok formal maupun informal organisasi (Masmuh, 2010: 6). Dalam Masmuh (2010: 5), Redding dan Sanborn menyatakan bahwa komunikasi organisasi adalah pengiriman dan penerimaan informasi dalam organisasi yang kompleks. Yang termasuk dalam bidang ini adalah komunikasi internal, hubungan manusia, hubungan persatuan pengelola, komunikasi downward atau komunikasi dari atasan kepada bawahan, komunikasi upward atau komunikasi dari bawahan kepada atasan, komunikasi horizontal atau komunikasi dari orang-orang yang sama level/tingkatnya dalam organisasi, keterampilan berkomunikasi dan berbicara, mendengarkan, menulis dan komunikasi evaluasi program. Pengelolaan keuangan daerah tidak akan berjalan dengan baik tanpa adanya komunikasi yang baik antara pimpinan dan bawahan.

Hasibuan (2003) mengartikan sumber daya manusia sebagai kemampuan terpadu dari daya pikir dan daya fisik yang dimiliki individu. Daya pikir merupakan kecerdasan yang dibawa dari lahir (modal dasar) sedangkan kecapakan diperoleh dari usaha (belajar dan pelatihan). Perilaku dan sifatnya ditentukan oleh keturunan dan lingkungannya, sedangkan prestasi kerjanya dimotivasi oleh keinginan untuk memenuhi kepuasannya. Penelitian Asrori (2014) mengungkapkan bahwa kapasitas perangkat desa dalam menyusun regulasi desa, baik dalam hal perencanaan, pelaksanaan, maupun dalam penyusunan peraturan desa dan keputusan kepala desa masih kurang, tingkat pemahaman perangkat desa dalam memahami manajemen sumber daya manusia masih kurang, seperti adanya loncatanloncatan dalam penyusunan dokumen perencanaan pembangunan. Hal tersebut menunjukkan bahwa sumber daya manusia sangat berpengaruh terhadap pengelolaan keuangan desa.

Mahoney et al. (1965) mendefinisikan kinerja manajerial berdasarkan beberapa fungsi manajemen yaitu seberapa jauh manager mampu melaksanakan fungsi-fungsi manajemen tersebut yang meliputi: perencanaan, investigasi, koordinasi, evaluasi, supervisi, pemilihan staf, negosiasi dan perwakilan. Pengertian kinerja instansi pemerintah menurut Lembaga Administrasi Negara Republik Indonesia (2003) adalah gambaran mengenai tingkat pencapaian sasaran ataupun tujuan instansi pemerintah sebagai penjabaran dari visi, misi dan strategi instansi pemerintah yang mengindikasikan tingkat 
keberhasilan dan kegagalan pelaksanaan kegiatan-kegiatan sesuai dengan program dan kebijaksanaan yang ditetapkan.

Pengelolaan keuangan desa menurut Peraturan Menteri Dalam Negeri Republik Indonesia Nomor 113 Tahun 2014 adalah keseluruhan kegiatan yang meliputi perencanaan, pelaksanaan, penatausahaan, pelaporan, dan pertanggungjawaban keuangan desa. pengelolaan keuangan desa merupakan hal yang sangat penting yang harus dilaksanakan oleh aparatur desa, dimana untuk meningkatkan kinerja pemerintah desa salah satunya adalah dengan melakukan pengelolaan keuangan desa secara lebih transparan, akuntabel, dan partisipatif serta sesuai dengan peraturan yang berlaku. Hasil penelitian Sugeng (2014) menunjukkan bahwa pengelolaan keuangan daerah berpengaruh terhadap kinerja pemerintah daerah. Apabila pengelolaan keuangan daerah dapat dikelola dengan efektif, efisien, transparan dan akuntabel maka hal tersebut dapat meningkatkan kinerja Pemerintah Daerah khususnya pada sektor pemenuhan pelayanan publik yang benar-benar dibutuhkan oleh masyarakat (Sugeng, 2014). Adanya pengelolaan keuangan daerah dapat meningkatkan kinerja suatu instansi pemerintah dengan melaksanakan kegiatan sesuai dengan tugas dan fungsinya secara efektif dan efisien, sehingga dengan adanya pengelolaan keuangan daerah dapat mendorong terwujudnya kinerja pemerintah daerah yang lebih berkualitas, bebas dari praktik korupsi, kolusi, dan nepotisme.

Pengelolaan keuangan desa merupakan variabel yang memediasi antara regulasi, komitmen organisasi, komunikasi, dan sumber daya manusia terhadap kinerja pemerintah desa. Semakin baik dan berkualitasnya regulasi, komitmen organisasi, komunikasi dan sumber daya manusia yang ada, maka akan meningkatkan pengelolaan keuangan desa. Dengan meningkatkan pengelolaan keuangan desa maka kinerja pemerintah desa juga semakin optimal. Hal ini ditunjukkan pada penelitian yang dilakukan oleh Fitriana (2015) yang meneliti tentang pengaruh sumber daya manusia, informasi keuangan desa, dan komitmen organisasi terhadap kinerja kepala desa dengan pengelolaan keuangan desa sebagai variabel intervening.

Berdasarkan uraian diatas, penelitian ini bertujuan untuk menguji dan menganalisis faktor-faktor yang mempengaruhi kinerja pemerintah desa terutama melalui pengelolaan keuangan desa. Adapun hipotesis yang dapat dirumuskan dalam penelitian ini adalah:

$\mathrm{H}_{\mathrm{a} 1} \quad$ : Regulasi berpengaruh signifikan terhadap pengelolaan keuangan desa.

$\mathrm{H}_{\mathrm{a} 2} \quad$ : Regulasi berpengaruh signifikan terhadap kinerja pemerintah desa.

$\mathrm{H}_{\mathrm{a} 3} \quad$ : Komitmen organisasi berpengaruh signifikan terhadap pengelolaan keuangan desa.

$\mathrm{H}_{a 4} \quad$ : Komitmen organisasi berpengaruh signifikan terhadap kinerja pemerintah desa.

$\mathrm{H}_{25} \quad$ : Komunikasi berpengaruh signifikan terhadap pengelolaan keuangan desa.

$\mathrm{H}_{\mathrm{a} 6} \quad$ : Komunikasi berpengaruh signifikan terhadap kinerja pemerintah desa. 
$\mathrm{H}_{\mathrm{a} 7} \quad$ : Sumber daya manusia berpengaruh signifikan terhadap pengelolaan keuangan desa.

$\mathrm{H}_{\mathrm{a} 8} \quad$ : Sumber daya manusia berpengaruh signifikan terhadap kinerja pemerintah desa.

$\mathrm{H}_{a 9} \quad$ : Pengelolaan keuangan desa berpengaruh signifikan terhadap kinerja pemerintah desa.

$\mathrm{H}_{\mathrm{a} 10}$ : Regulasi, komitmen organisasi, komunikasi, dan sumber daya manusia berpengaruh signifikan terhadap kinerja pemerintah desa melalui pengelolaan keuangan desa.

\section{Metodologi}

Penelitian ini merupakan penelitian kuantitatif yang menggunakan data berupa angka-angka yang kemudian akan dianalisis menggunakan statistik. Populasi dalam penelitian ini adalah seluruh aparatur desa yang terdiri dari kepala desa sebagai pemegang kekuasaan pengelolaan keuangan desa, dan Pelaksana Teknis Pengelolaan Keuangan Desa (PTPKD), yang terdiri dari sekretaris desa, kepala seksi/kaur dan bendahara desa pada 209 desa di Kabupaten Bondowoso. Sampel dalam penelitian ini berjumlah 187 orang, yang terdiri dari kepala desa, sekretaris desa, kepala seksi/kaur dan bendahara desa, serta operator desa yang terlibat langsung dalam pengelolaan keuangan desa. Teknik pengambilan sampel dalam penelitian ini menggunakan purposive sampling. Metode pengumpulan data yang digunakan dalam penelitian ini adalah sebagai berikut:

1. Observasi, yaitu pengumpulan data dengan cara melakukan pengamatan langsung terhadap responden penelitian.

2. Kuesioner, yaitu teknik pengumpulan data yang dilakukan dengan cara memberikan sejumlah pertanyaan tertulis secara terstruktur kepada responden penelitian berkaitan dengan tanggapannya terhadap berbagai variabel yang diteliti dalam penelitian ini.

Untuk memberikan gambaran yang jelas dan memudahkan dalam melakukan penelitian ini, maka perlu dibuat definisi operasional variabel yang akan diteliti sebagai dasar dalam menyusun kuesioner penelitian. Definisi operasional tersebut dapat dijelaskan sebagai berikut:

1. Regulasi. Regulasi yang dimaksud dalam penelitian ini adalah sekumpulan peraturan tentang pengelolaan keuangan desa, yang berasal dari pemerintah pusat, pemerintah daerah maupun dari pemerintah desa sendiri.

2. Komitmen organisasi. Komitmen organisasi merupakan tingkat sampai sejauh mana apa seorang karyawan memihak pada suatu organisasi tertentu dan tujuantujuannya, serta berniat mempertahankan keanggotaannya dalam organisasi tersebut (Lubis, 2010). 
3. Komunikasi. Komunikasi dalam penelitian ini adalah media yang digunakan untuk mengemukakan ide dan gagasan dalam rangka menunjang pelaksanaan tugas dan tanggung jawab yang diberikan sebagai pengelolaan keuangan desa pada pemerintah desa.

4. Sumber daya manusia. Sumber daya manusia dalam penelitian ini adalah kemampuan yang dimiliki oleh perangkat desa dalam melaksanakan tugasnya berdasarkan kompetensi, latar belakang pendidikan, pelatihan yang diperoleh, pemahaman tentang tupoksi pekerjaannya, kesiapan dalam melakukan perubahan regulasi dan kebijakan pengelolaan keuangan desa.

5. Kinerja pemerintah desa. Kinerja pemerintah desa adalah kinerja kepala desa yang dibantu perangkat desa sebagai unsur penyelenggara pemerintahan desa. Untuk variabel kinerja pemerintah desa, pengukurannya berdasarkan Undang-undang Nomor 6 Tahun 2014 tentang desa beserta peraturan pelaksanaannya.

6. Pengelolaan keuangan desa. Pengelolaan keuangan desa adalah keseluruhan proses kegiatan yang meliputi perencanaan, pelaksanaan, penatausahaan, pelaporan, dan pertanggungjawaban keuangan desa. Pelaku utama pengelolaan keuangan desa adalah kepala desa selaku pemegang kekuasaan pengelolaan keuangan desa, yang dibantu oleh PTPKD yang berasal dari unsur perangkat desa yang terdiri dari: sekretaris desa, kepala seksi, dan bendahara.

Pengujian validitas dilakukan dengan confirmatory factor analysis (CFA) dengan melihat dari nilai faktor loading-nya. Syarat yang harus dipenuhi, pertama, loading factor harus signifikan. Oleh karena loading factor yang signifikan bisa jadi masih rendah nilainya, maka standardized loading estimated harus sama dengan 0.05 atau lebih, dan idealnya harus 0.07 (Ghozali, 2011: 137-138). Jadi item pertanyaan yang memiliki loading factor $\geq$ 0,50 dapat dikatakan valid. Uji reliabilitas dalam penelitian ini menggunakan koefisien Cronbach Alpha (a), walaupun kenyataannya Cronbach Alpha memberikan reliabilitas yang lebih rendah (under estimate) dibandingkan dengan construct reliability. Construct reliability 0.70 atau lebih menunjukkan reliabilitas yang baik, sedangkan reliabilitas $0.60-0.70$ masih dapat diterima dengan syarat validitas indikator dalam model baik (Ghozali, 2011: 140).

Setelah dilakukan uji validitas dan uji reliabilitas pada masing-masing variabel laten, maka dilakukan uji asumsi untuk melihat apakah prasyarat yang diperlukan dalam pemodelan regresi confirmatory dapat terpenuhi. Prasyarat yang harus dipenuhi adalah asumsi multivariat normal, tidak adanya multikolinearitas, dan outliers. Uji normalitas dilakukan dengan menggunakan kriteria critical ratio skewness value sebesar $\pm 2,58$ pada tingkat signifikansi 0,01 . Data dapat disimpulkan mempunyai distribusi normal jika nilai critical ratio skewness value di bawah harga mutlak 2,58 (Ghozali, 2011: 226). 
Multikolinearitas dapat dilihat melalui determinan matrik kovarians. Nilai determinan yang sangat kecil menunjukkan indikasi terdapatnya masalah multikolinearitas atau singularitas, sehingga data itu tidak dapat digunakan untuk untuk penelitian (Ghozali, 2011:230). Deteksi terhadap multivariat outliers dilakukan dengan memperhatikan nilai mahalanobis distance. Kriteria yang digunakan adalah berdasarkan nilai Chi-square pada derajat kebebasan (degree of freedom) tertentu sesuai dengan jumlah variabel indikator pada tingkat signifikansi $p<0,05$. Kasus yang mempunyai nilai mahalanobis distance lebih besar dari Chi-square yang disyaratkan, maka kasus tersebut adalah multivariate outliers (Ghozali, 2011: 227).

\section{Hasil dan Pembahasan}

Hasil uji validitas pada konstruk regulasi menunjukkan bahwa terdapat dua indikator yang tidak valid, yaitu indikator konsistensi pelaksanaan dan kemudahan pelaksanaan. Uji validitas pada konstruk sumber daya manusia menunjukkan terdapat satu indikator yang tidak valid, yaitu indikator mempunyai komitmen yang tinggi. Uji validitas pada konstruk pengelolaan keuangan desa menunjukkan terdapat satu indikator yang tidak valid, yaitu indikator pemungutan pajak. Indikator dinyatakan tidak valid karena memiliki nilai loading factor dibawah 0,5 dengan nilai probabilitas lebih kecil dari 0,05, sehingga harus dikeluarkan dari model untuk dilakukan pengujian berikutnya.

Untuk uji asumsi Structural Equational Modelling (SEM), dari hasil uji normalitas data diketahui bahwa nilai critical ratio $(\mathrm{CR})$ semua indikator menunjukkan distribusi normal karena nilainya berada diantara $-2,58$ sampai dengan 2,58 . Sedangkan uji multivariat memberikan nilai CR 0,070 yaitu berada diantara nilai -2,58 sampai dengan 2,58 sehingga secara multivariat berdistribusi normal. Jadi dapat disimpulkan bahwa data dalam penelitian ini berdistribusi normal baik secara univariat maupun secara multivariat. Hasil pengujian multikolinearitas terhadap data dalam penelitian ini dengan menggunakan program AMOS memberikan nilai determinan matriks kovarians sebesar 0,096. Nilai ini jauh dari angka nol sehingga dapat disimpulkan bahwa tidak ada masalah multikolinearitas atau singularitas pada data yang dianalisis. Kriteria yang digunakan dalam penelitian ini adalah berdasarkan nilai Chi-square pada derajat kebebasan (degree of freedom) 26 yaitu jumlah variabel indikator pada tingkat signifikansi $p<0,01$. Nilai mahalanobis distance $x^{2}(0,01 ; 26)$ adalah sebesar 45,641. Hal ini berarti semua kasus yang mempunyai nilai mahalanobis distance yang lebih besar dari 45,641 adalah multivariate outliers. Hasil uji outliers dalam penelitian ini menunjukkan bahwa tidak ada data yang memiliki nilai mahalanobis distance lebih besar dari 45,641 dan nilai $p<0,05$, sehingga dapat disimpulkan bahwa tidak ada multivariate outliers dalam data yang dianalisis. Setelah dilakukan uji validitas dan reliabilitas pada semua variabel laten yang memberikan hasil valid dan reliabel, data multivariate 
normal, tidak terjadi multikolinearitas dan tidak terjadi data outliers, maka variabel tersebut dapat diuji lebih lanjut dengan uji kesesuaian model dan uji kausalitas.

Evaluasi terhadap kesesuaian model persamaan struktural dilakukan dengan membandingkan nilai indeks-indeks fit yang dihasilkan dari model dengan nilai indeksindeks fit yang direkomendasikan, dimana hasil pengujian Chi-square sebesar 299,599 dengan probabilitas 0,337 menunjukkan model sangat fit. Nilai untuk kriteria lainnya juga sesuai dengan yang direkomendasikan, kecuali GFI, AGFI, dan RMSEA yang berada sedikit dibawah kriteria yang direkomendasikan. Dengan demikian dapat dikatakan bahwa model dapat diterima karena ada kesesuaian antara model dengan data.

Langkah selanjutnya adalah menguji kausalitas hipotesis yang telah dikembangkan. Hasil uji kausalitas menunjukkan bahwa terdapat lima jalur yang signifikan pada taraf 0,05 , yaitu dari komitmen organisasi ke pengelolaan keuangan desa, dari komitmen organisasi ke kinerja pemerintah desa, dari sumber daya manusia ke pengelolaan keuangan desa, dari komitmen organisasi ke kinerja pemerintah desa, dan dari pengelolaan keuangan desa ke kinerja pemerintah desa. Sedangkan empat jalur yang tidak signifikan yaitu dari regulasi ke pengelolaan keuangan desa, dari regulasi ke kinerja pemerintah desa, dari komunikasi ke pengelolaan keuangan, dan dari komunikasi ke kinerja pemerintah desa. Sedangkan untuk variabel yang signifikan terhadap kinerja pemerintah desa melalui variabel intervening pengelolaan keuangan adalah variabel komitmen organisasi dan kinerja pemerintah desa.

\section{Kesimpulan}

Dari hasil penelitian yang telah dilakukan, maka dapat diambil beberapa kesimpulan, yaitu:

a. Regulasi tidak berpengaruh terhadap pengelolaan keuangan desa dan kinerja pemerintah desa. Dalam hal ini aparatur desa masih mengalami kesulitan dalam memahami dan mengimplementasikan berbagai bentuk peraturan yang dikeluarkan oleh pemerintah pusat maupun pemerintah desa, sehingga dalam menjalankan tugas pokok dan fungsinya masih belum sepenuhnya menerapkan peraturan yang berlaku.

b. Komitmen organisasi berpengaruh signifikan positif terhadap pengelolaan keuangan desa dan kinerja pemerintah desa.

c. Komunikasi tidak berpengaruh terhadap pengelolaan keuangan desa dan kinerja pemerintah desa. Dalam hal ini komunikasi masih belum sepenuhnya diterapkan dalam melakukan pengelolaan keuangan desa, misalnya ketidaktertiban pembuatan RKP desa maupun APBD desa, ketidaktertiban waktu penyetoran SPJ, dan sebagainya. 
d. Sumber daya manusia berpengaruh signifikan positif terhadap pengelolaan keuangan desa dan kinerja pemerintah desa.

e. Pengelolaan keuangan desa berpengaruh signifikan positif terhadap kinerja pemerintah desa.

f. Komitmen organisasi dan sumber daya manusia berpengaruh signifikan positif terhadap kinerja pemerintah desa melalui pengelolaan keuangan desa.

Dalam penelitian ini masih terdapat beberapa keterbatasan terkait kuesioner yang disebarkan, antara lain jumlah kepala desa yang menjadi responden dalam penelitian ini masih sedikit, sedangkan pemegang kekuasaan tertinggi atas pengelolaan keuangan desa adalah kepala desa, sehingga semua keputusan berada di tangan kepala desa. Selain iu penelitian ini terbatas hanya pada aparatur desa di Kabupaten Bondowoso.

\section{Saran}

Dari hasil penelitian yang telah dilakukan terdapat beberapa saran, yaitu:

1. Untuk penelitian selanjutnya disarankan untuk lebih menambah responden kepala desa selaku pemegang kekuasaan pengelolaan keuangan desa.

2. Untuk penelitian selanjutnya disarankan untuk menambah teknik pengumpulan data dengan wawancara langsung kepada responden.

3. Penelitian ini perlu dikembangkan lebih jauh lagi untuk mendapatkan hasil empirik yang lebih kuat, yaitu dengan menambah variabel lain yang dapat mempengaruhi kinerja, misalnya budaya organisasi, motivasi, kepemimpinan, dan sebagainya, atau mengubah regulasi menjadi variabel intervening.

\section{Daftar Referensi}

Asrori. 2014. Kapasitas Perangkat Desa dalam Penyelenggaraan Pemerintahan Desa di Kabupaten Kudus. Jurnal Bina Praja Edisi Juni. 6 (2): 101-106.

Fitriana, Dian. 2015. Pengaruh Sumber Daya Manusia, Informasi Keuangan Desa dan Komitmen Organisasi terhadap Kinerja Kepala Desa dengan Pengelolaan Keuangan Desa sebagai variabel intervening. Tesis. Surabaya: Program Studi Magister Akuntansi Universitas Airlangga.

Ghozali, Imam. 2011. Model Persamaan Struktural Konsep dan Aplikasi dengan Program Amos 22.0. Semarang: Badan Penerbit Universitas Diponegoro.

Halim, Rahmawati. 2012. Pengaruh Komitmen Organisasi dan Peranan Kepemimpinan dalam meningkatkan Pengelolaan Keuangan Daerah pada Dinas Pendapatan, Pengelolaan Keuangan dan Asset Kabupaten Banggai Kepulauan. Jurnal Academica Fisip Untad Februari. 4 (1): 816-829.

Hasibuan, Malayu S.P. 2003. Manajemen Sumber Daya Manusia Edisi Revisi. Jakarta: Bumi Aksara.

Hoesada, Jan. 2016. Bunga Rampai Akuntansi Pemerintahan. Jakarta: Salemba Empat. 
Lembaga Administrasi Negara Republik Indonesia. 2003. Pedoman Penyusunan Pelaporan Akuntabilitas Kinerja Instansi Pemerintah.

Lubis, Arfan Ikhsan. 2010. Akuntansi Keperilakuan Edisi 2. Jakarta: Salemba Empat.

Mahoney, T. A., Jerdee, H., and Caroll, S. J. 1965. The Job(s) of Management, Industrial Relations 2: 97-110.

Masmuh, Abdullah. 2010. Komunikasi Organisasi dalam Perspektif Teori dan Praktek. Malang: UMM Press.

Peraturan Menteri Dalam Negeri Republik Indonesia Nomor 113 Tahun 2014 tentang Pengelolaan Keuangan Desa.

Peraturan Pemerintah Republik Indonesia Nomor 60 Tahun 2014 tentang Dana Desa yang Bersumber dari Anggaran Pendapatan dan Belanja Negara.

Soeprapto, Maria Farida Indrati. 1998. Ilmu Perundang-undangan: Dasar-dasar dan Pembentukannya. Yogyakarta: Kanisius

Solekhan, Moch. 2014. Penyelenggaraan Pemerintahan Desa Berbasis Partisipasi Masyarakat. Malang: Setara Press.

Sugeng. 2014. Faktor-faktor yang mempengaruhi Pengelolaan Keuangan Daerah dan implikasinya terhadap Kinerja Pemerintah Daerah di Kabupaten Kediri. Jurnal Riset Ekonomi dan Bisnis Juli. 1 (2): 16-26.

Undang-undang Republik Indonesia Nomor 32 Tahun 2004 tentang Pemerintahan Daerah, yang diganti dengan Undang-undang Nomor 23 Tahun 2014 tentang Pemerintahan Daerah.

Undang-undang Nomor 12 Tahun 2011 tentang Pembentukan Peraturan PerundangUndangan.

Undang-undang Republik Indonesia Nomor 6 Tahun 2014 tentang Desa. 


\section{Lampiran Uji SEM}

Estimates (Group number 1 - Default model)

Scalar Estimates (Group number 1 - Default model)

Maximum Likelihood Estimates

Regression Weights: (Group number 1 - Default model)

\begin{tabular}{|c|c|c|c|c|c|c|c|}
\hline & & & Estimate & S.E. & C.R. & $P$ & Label \\
\hline $\begin{array}{l}\text { Pengelolaan_Keuangan } \\
\text { Desa }\end{array}$ & $<--$ & $\begin{array}{l}\text { Komitmen_ } \\
\text { Organisasi }\end{array}$ & ,323 & ,117 & 2,765 & ,006 & par_22 \\
\hline $\begin{array}{l}\text { Pengelolaan_Keuangan } \\
\text { Desa }\end{array}$ & $<--$ & Regulasi &, 013 & ,064 & ,210 & ,834 & par_25 \\
\hline $\begin{array}{l}\text { Pengelolaan_Keuangan } \\
\text { Desa }\end{array}$ & $<---$ & SDM & ,319 & ,134 & 2,373 & ,018 & par_27 \\
\hline $\begin{array}{l}\text { Pengelolaan_Keuangan } \\
\text { Desa }\end{array}$ & $<--$ & Komunikasi & ,033 & ,110 & ,301 & ,763 & par_29 \\
\hline Kinerja Pemdes & $<--$ & $\begin{array}{l}\text { Pengelolaan_ } \\
\text { Keuangan } \\
\text { Desa }\end{array}$ & ,584 & ,175 & 3,329 & $\star * *$ & par_6 \\
\hline Kinerja Pemdes & $<--$ & $\begin{array}{l}\text { Komitmen_ } \\
\text { Organisasi }\end{array}$ & , 269 & ,121 & 2,227 & ,026 & par_23 \\
\hline Kinerja Pemdes & $<---$ & Komunikasi &,- 071 & ,091 &,- 782 & ,434 & par_24 \\
\hline Kinerja Pemdes & $<--$ & Regulasi & ,096 & ,055 & 1,760 & ,078 & par_26 \\
\hline Kinerja Pemdes & $<--$ & SDM & ,272 & ,121 & 2,260 & ,024 & par_28 \\
\hline X23 & $<--$ & $\begin{array}{l}\text { Komitmen_ } \\
\text { Organisasi }\end{array}$ & ,592 & ,170 & 3,489 & *** & par_1 \\
\hline Y21 & $<--$ & $\begin{array}{l}\text { Kinerja } \\
\text { Pemdes }\end{array}$ & 1,000 & & & & \\
\hline Y22 & $<---$ & $\begin{array}{l}\text { Kinerja } \\
\text { Pemdes }\end{array}$ & 1,273 & ,295 & 4,319 & *** & par_2 \\
\hline Y23 & $<---$ & $\begin{array}{l}\text { Kinerja } \\
\text { Pemdes }\end{array}$ & 1,242 & ,290 & 4,288 & *** & par_3 \\
\hline Y24 & $<--$ & $\begin{array}{l}\text { Kinerja } \\
\text { Pemdes }\end{array}$ & 1,098 & ,265 & 4,141 & *** & par_4 \\
\hline Y25 & $<--$ & $\begin{array}{l}\text { Kinerja } \\
\text { Pemdes }\end{array}$ & 1,414 & ,331 & 4,267 & $\star * *$ & par_5 \\
\hline $\mathrm{X} 13$ & $<--$ & Regulasi & ,623 & ,098 & 6,340 & *** & par_7 \\
\hline X12 & $<--$ & Regulasi & ,789 & 111 & 7,126 & *** & par_8 \\
\hline
\end{tabular}




\begin{tabular}{|c|c|c|c|c|c|c|c|}
\hline & & & Estimate & S.E. & C.R. & $P$ & Label \\
\hline $\mathrm{X} 11$ & $<--$ & Regulasi & 1,000 & & & & \\
\hline $\mathrm{X} 16$ & $<--$ & Regulasi & ,671 & ,108 & 6,241 & *** & par_9 \\
\hline $\mathrm{X} 17$ & $<--$ & Regulasi & ,706 & ,103 & 6,857 & 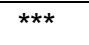 & par_10 \\
\hline X32 & $<---$ & Komunikasi & \begin{tabular}{|l|}
, 962 \\
\end{tabular} & 296 & 3,250 & ,001 & par_11 \\
\hline X22 & $<---$ & $\begin{array}{l}\text { Komitmen_ } \\
\text { Organisasi }\end{array}$ & 1,000 & & & & \\
\hline X21 & $<--$ & $\begin{array}{l}\text { Komitmen_ } \\
\text { Organisasi }\end{array}$ & 1,220 & ,272 & 4,485 & $* * *$ & par_12 \\
\hline X24 & $<---$ & $\begin{array}{l}\text { Komitmen_ } \\
\text { Organisasi }\end{array}$ & ,886 & ,200 & 4,438 & $* * *$ & par_13 \\
\hline X25 & $<--$ & $\begin{array}{l}\text { Komitmen_ } \\
\text { Organisasi }\end{array}$ & ,633 & ,184 & 3,432 & $* * *$ & par_14 \\
\hline Y12 & $<--$ & $\begin{array}{l}\text { Pengelolaan_ } \\
\text { Keuangan } \\
\text { Desa }\end{array}$ & 1,020 & ,229 & 4,450 & $* * *$ & par_15 \\
\hline Y14 & $<--$ & $\begin{array}{l}\text { Pengelolaan_ } \\
\text { Keuangan } \\
\text { Desa }\end{array}$ & ,983 & ,233 & 4,217 & $* * *$ & par_16 \\
\hline Y11 & $<---$ & $\begin{array}{l}\text { Pengelolaan_ } \\
\text { Keuangan } \\
\text { Desa }\end{array}$ & ,985 & ,217 & 4,547 & $* * *$ & par_17 \\
\hline Y15 & $<---$ & $\begin{array}{l}\text { Pengelolaan_ } \\
\text { Keuangan } \\
\text { Desa }\end{array}$ & 1,000 & & & & \\
\hline X31 & $<--$ & Komunikasi & 1,074 & ,328 & 3,269 & ,001 & par_18 \\
\hline X33 & $<--$ & Komunikasi & 1,000 & & & & \\
\hline $\mathrm{X} 44$ & $<--$ & SDM & 1,104 & ,245 & 4,511 & $* * *$ & par_19 \\
\hline $\mathrm{X} 43$ & $<--$ & SDM & 1,115 & ,240 & 4,654 & $* * *$ & par_20 \\
\hline X42 & $<--$ & SDM & ,925 & 200 & 4,627 & *** & par_21 \\
\hline $\mathrm{X} 45$ & $<--$ & SDM & 1,000 & & & & \\
\hline
\end{tabular}

Standardized Regression Weights: (Group number 1 - Default model)

\begin{tabular}{|lll|l|}
\hline & & \multicolumn{1}{c|}{ Estimate } \\
\hline Pengelolaan_Keuangan Desa & $<--$ & Komitmen_Organisasi &, 346 \\
\hline Pengelolaan_Keuangan Desa & $<---$ & Regulasi &, 021 \\
\hline Pengelolaan_Keuangan Desa & $<---$ & SDM &, 323 \\
\hline
\end{tabular}




\begin{tabular}{|c|c|c|c|}
\hline & & & Estimate \\
\hline Pengelolaan_Keuangan Desa & $<--$ & Komunikasi & ,037 \\
\hline Kinerja Pemdes & $<---$ & Pengelolaan_Keuangan Desa & ,435 \\
\hline Kinerja Pemdes & $<--$ & Komitmen_Organisasi & ,332 \\
\hline Kinerja Pemdes & $<--$ & Komunikasi &,- 091 \\
\hline Kinerja Pemdes & $<<--$ & Regulasi & , 175 \\
\hline Kinerja Pemdes & $<---$ & SDM & ,318 \\
\hline $\mathrm{X} 23$ & $<---$ & Komitmen_Organisasi & ,367 \\
\hline Y21 & $<--$ & Kinerja Pemdes &, 474 \\
\hline Y22 & $<---$ & Kinerja Pemdes &, 547 \\
\hline Y23 & $<---$ & Kinerja Pemdes & ,498 \\
\hline Y24 & $<--$ & Kinerja Pemdes &, 482 \\
\hline Y25 & $<--$ & Kinerja Pemdes &, 581 \\
\hline $\mathrm{X} 13$ & $<--$ & Regulasi &, 516 \\
\hline $\mathrm{X} 12$ & $<---$ & Regulasi & ,630 \\
\hline $\mathrm{X} 11$ & $<---$ & Regulasi &, 821 \\
\hline $\mathrm{X} 16$ & $<---$ & Regulasi &, 523 \\
\hline $\mathrm{X} 17$ & $<---$ & Regulasi & ,584 \\
\hline $\mathrm{X} 32$ & $<<--$ & Komunikasi &, 551 \\
\hline $\mathrm{X} 22$ & $<--$ & Komitmen_Organisasi & ,564 \\
\hline $\mathrm{X} 21$ & $<--$ & Komitmen_Organisasi & ,607 \\
\hline $\mathrm{X} 24$ & $<--$ & Komitmen_Organisasi &, 504 \\
\hline $\mathrm{X} 25$ & $<---$ & Komitmen_Organisasi & ,363 \\
\hline Y12 & $<---$ & Pengelolaan_Keuangan Desa &, 542 \\
\hline Y14 & $<---$ & Pengelolaan_Keuangan Desa &, 532 \\
\hline Y11 & $<---$ & Pengelolaan_Keuangan Desa & ,528 \\
\hline Y15 & $<---$ & Pengelolaan_Keuangan Desa &, 545 \\
\hline $\mathrm{X} 31$ & $<--$ & Komunikasi &, 517 \\
\hline X33 & $<--$ & Komunikasi &, 550 \\
\hline $\mathrm{X} 44$ & $<--$ & SDM &, 568 \\
\hline $\mathrm{X} 43$ & $<---$ & SDM & ,604 \\
\hline $\mathrm{X} 42$ & $<---$ & SDM &, 550 \\
\hline $\mathrm{X} 45$ & $<--$ & SDM &, 520 \\
\hline
\end{tabular}

